\title{
Perennial Wheat Germ Plasm Lines Resistant to Eyespot, Cephalosporium Stripe, and Wheat Streak Mosaic
}

\author{
C. M. Cox, Former Graduate Research Assistant, Department of Plant Pathology, T. D. Murray, Professor, De- \\ partment of Plant Pathology, and S. S. Jones, Associate Professor, Department of Crop and Soil Sciences, Washing- \\ ton State University, Pullman
}

\begin{abstract}
Cox, C. M., Murray, T. D., and Jones S. S. 2002. Perennial wheat germ plasm lines resistant to eyespot, Cephalosporium stripe, and wheat streak mosaic. Plant Dis. 86:1043-1048.

A perennial wheat cropping system on the Palouse Prairie of eastern Washington may provide an alternative to the Federal Conservation Reserve Program and reduce soil erosion while providing a harvestable crop for growers. Twenty-four perennial wheat germ plasm lines resulting from crosses between wheat and wheatgrass were evaluated under controlled environment conditions for resistance to Wheat streak mosaic virus (WSMV), Cephalosporium gramineum, and Tapesia yallundae (anamorph Pseudocercosporella herpotrichoides var. herpotrichoides). Perennial wheat lines SS452, SS103, SS237, MT-2, and PI 550713 were resistant to all three pathogens. Eight lines $(33 \%)$ were resistant to WSMV at $21^{\circ} \mathrm{C}$ and $25^{\circ} \mathrm{C}$; AT3425 was resistant to WSMV at $21^{\circ} \mathrm{C}$ but not at $25^{\circ} \mathrm{C}$. Thirteen lines $(54 \%)$ were highly to moderately resistant to $C$. gramineum. Thirteen lines (54\%) were resistant to T. yallundae in each experiment, but the reactions of four lines differed between experiments. The wheatgrasses Thinopyrum intermedium (PI 264770) and Thinopyrum ponticum (PI 206624) are reported as new sources of resistance to T. yallundae. Perennial wheat must have resistance to these diseases in order to be feasible as a crop in the Pacific Northwest.
\end{abstract}

The Palouse Prairie of eastern Washington was identified in the 1997 USDA National Resources Inventory as one of the most highly erodible areas in the United States. It is estimated that $10 \%$ of the original topsoil in eastern Washington has been lost since cultivation began in the region in the late 1800s (32). Furthermore, runoff from agricultural land reduces water quality in streams and rivers (34), and dust is the leading air pollutant in Washington (33).

Healthy stands of perennial grasses like those established under the Federal Conservation Reserve Program (CRP) reduce soil erosion (17) and competition from weeds (8), restore soil nutrients (9), increase soil quality (11), and increase wildlife habitat (24). Over 29 million acres of highly erodible agricultural land in the United States are currently enrolled in CRP with over 2 million acres located in Washington, Oregon, and Idaho. However, there are more acres of land considered highly erodible than can be enrolled in the current program. Thus, alternative solutions for soil erosion control are needed that are ecologically and economically sustainable.

Corresponding author: T. D. Murray

E-mail: tim_murray@wsu.edu

Accepted for publication 9 May 2002.

Publication no. D-2002-0722-04R

(C) 2002 The American Phytopathological Society
Perennial wheat has the potential to convert unprofitable land back into production, save state and federal money, conserve agricultural land and natural resources, and provide a profitable crop for growers.

Past efforts to develop perennial wheat for grain production were begun in the 1920s (30,31). Sando hybridized domestic wheat with wheatgrass (then called Agropyron spp.) and selected for perennial habit (36), as did Suneson (28) and Suneson and Pope (29). The best perennial lines of those programs yielded only $60 \%$ of the grain of the best annual varieties and the project was abandoned because yield was the ultimate goal (29).

The loss of topsoil that results in nonpoint source water pollution and reduces soil productivity over time has resulted in a renewed interest in perennial wheat. Cultural practices such as modification of seeding date and tillage that are used to reduce disease in conventional and no-till wheat production systems are of limited value in a perennial wheat crop. Inoculum of many pathogens is capable of surviving from crop to crop in senescent tissue, in live root and crown tissue, and in perennial plants (4). Perennial wheat must contain appropriate disease resistance genes for locally important diseases for it to be feasible. Furthermore, resistance must be durable and suppress disease below an economic threshold to reduce external inputs and enhance the profitability of perennial wheat (37). It is possible that combining genotypes and pyramiding re- sistance genes from wild relatives of wheat that durable resistance can be achieved within a perennial wheat cropping system.

Perennial wheat is essentially a notillage system with persistent crowns and residue in the soil and as such, could potentially serve as a reservoir for pathogens that survive in plant debris (4). Eyespot, Cephalosporium stripe, and wheat streak mosaic (WSM) caused by Tapesia yallundae Wallwork \& Spooner and T. acuformis (Boerma, Pieters \& Hamers) Crous (anamorphs Pseudocercosporella herpotrichoides (Fron.) Deighton var. herpotrichoides and var. acuformis, respectively), Cephalosporium gramineum Nisikado \& Ikata, and Wheat streak mosaic virus (WSMV), respectively, are among the most significant diseases in the intermediate- and low-rainfall regions of Washington for which perennial wheat is being developed (12). The fungi that cause eyespot and Cephalosporium stripe survive in crop residues (38) and thus, may be favored in a perennial wheat cropping system. Likewise, annual wheat escapes infection by WSMV in most years because it dies and does not overlap with potential reservoir hosts. Perennial wheat, by virtue of its regrowth after harvest, may become infected by WSMV resulting in less productivity, shorter stand duration, and it may serve as an inoculum reservoir for nearby annual small grain crops.

Several wheatgrasses are resistant to many of the diseases that infect annual wheat, which include Cephalosporium stripe, WSM, stripe rust, leaf rust, and barley yellow dwarf $(6,7,13,15)$. Despite efforts by breeders to exploit the genetic resources of the wheatgrasses and other members of the Triticeae, winter wheat cultivars adapted for production in the Pacific Northwest with highly effective resistance to Cephalosporium stripe and/or WSM are not available (13). Control of these diseases has relied on cultural practices such as elimination of volunteer wheat to prevent carryover of virus and vectors from spring to winter crops, 3-year rotations between susceptible wheat crops, destruction of residue by tillage or burning, and delayed seeding in the autumn $(23,38)$. Eyespot is controlled largely with diseaseresistant cultivars and foliar fungicides $(10,22,23)$. Cultural practices such as seeding date and tillage for disease control will not be feasible in a perennial wheat crop- 
ping system and, therefore, breeding for combined resistance to eyespot, Cephalosporium stripe, and WSM is critical for the successful development of commercially acceptable perennial wheat cultivars.

The objective of this study was to identify perennial breeding lines [wheatgrass (Thinopyrum spp.) $\times$ wheat] with individual or combined resistance to eyespot, Cephalosporium stripe, and WSM for use as parents in development of perennial wheat.

\section{MATERIALS AND METHODS}

Perennial wheat germ plasm. Twentyfour perennial wheat germ plasm lines were evaluated. Eighteen of the 24 lines originated from the Sando and Suneson collections of annual wheat cultivars (Triticum spp.) hybridized with Agropyron elongatum (synonym Thinopyron ponticum Barkworth \& Dewey, $2 \mathrm{n}=10 \mathrm{x}=70$ ) or $A$. intermedium (synonym Thinopyron intermedium (Host) Barkworth \& Dewey, $2 \mathrm{n}=$ $6 x=42$ ). It should be noted that the taxonomy of the wheatgrasses is in flux. Currently accepted names based on chromosome number are used in this paper except where consistency with previous work is intended. These lines, designated "SS", represent advanced yet heterogeneous genotypes with varying chromosome constitutions from 42 to 56 (data not presented). AT3425 (Agrotriticum No. 3425; wheat $\times$ Thinopyron ponticum), PI 550713 (wheat $\times$ Thinopyron ponticum: 14 Thinopyrum chromosomes +3 wheatThinopyrum translocated chromosomes) and PI 550715 lines are perennial amphiploids with 56 chromosomes; Montana-2 (MT-2; Triticum durum x Thinopyron intermedium) is not stable (14). The perennial wheatgrasses Thinopyron intermedium (PI 264770) and Thinopyron ponticum (PI 206624) were also included in this study.

Wheat streak mosaic. Stephens winter wheat (CI 17596) is highly susceptible to WSMV. It was used as a susceptible control and was mock-inoculated with buffer + diatomaceous earth for the negative control. WSMV was cultured in Daws winter wheat (CI 17419) and used as the inoculum source.

Seeds of each genotype were imbibed at $4^{\circ} \mathrm{C}$ for 4 days on moist filter paper in petri dishes to synchronize germination and then sown five per pot in $8.9-\mathrm{cm}$-square pots filled with Thatuna silt loam (TSL)/ vermiculite/sand $\operatorname{mix}(90: 5: 5$, wt/wt/wt), $\mathrm{pH}$ 4.5. Experimental and source plants were grown in a growth chamber at 21 to $22^{\circ} \mathrm{C}$ with a $12-\mathrm{h}$ photoperiod. Plants were fertilized every 2 weeks by adding a solution of $300 \mathrm{mg} /$ liter Nutriculture (20-20-20 N-P-K, Plant Marvel Lab, Chicago, IL) to each pot. Plants were thinned to three per pot prior to inoculation.

Pots were arranged in a randomized complete block design with five replicates and the experiment was repeated twice.
The third experiment differed from the first two in that (i) only lines identified as resistant from the first two experiments were included, (ii) the temperature in the growth chamber was raised to $25^{\circ} \mathrm{C} 18$ days after the second inoculation, and (iii) plants were grown for another 2 weeks after raising the temperature.

Inoculum preparation and inoculation. The WSMV strain used throughout this study was the Washington/Idaho isolate registered in GenBank (Accession No. AF034415, courtesy of P. McCarthy and P. Berger, University of Idaho). Inoculum was extracted from infected source plants by grinding young, symptomatic leaves with a mortar and pestle in $0.01 \mathrm{M}$ sodium phosphate buffer (1:10, wt/vol), pH 7.4, and diatomaceous earth $(0.01 \mathrm{~g} / \mathrm{ml})$. Test plants were inoculated at the two- to threeleaf stage by sandwiching the second leaf in cheesecloth saturated with inoculum between the thumb and forefinger, and rubbing the blade once from base to tip (18). The third leaf of each plant was inoculated 8 to 10 days after the first inoculation.

Disease evaluation. Plants were visually evaluated for the presence or absence of WSM symptoms prior to harvest. Eighteen days after the second inoculation the youngest leaves of all plants in each pot were harvested (inoculated leaves were avoided) and tested for the presence of WSMV by indirect enzyme-linked immunosorbent assay (ELISA) (3). Plant tissue was cut into 1 - to $3-\mathrm{cm}$ pieces, frozen in liquid nitrogen, and ground with a mortar and pestle. Carbonate coating buffer at a concentration of $0.02 \mathrm{M}, \mathrm{pH} 9.5$ was added $(1: 10, \mathrm{wt} / \mathrm{vol})$ and the tissue was further ground until the liquid turned dark green. To individual wells of a 96-well, flat bottom, ELISA plate (Corning Glass Works, Corning, NY), $200 \mu$ of each treatment sample was added. Plates were incubated at room temperature for $2 \mathrm{~h}$, and then rinsed with ELISA wash $\left(0.8 \mathrm{~g} \mathrm{KH}_{2} \mathrm{PO}_{4}\right.$, $0.8 \mathrm{~g} \mathrm{KCl}, 4.6 \mathrm{~g}$ anhydrous $\mathrm{NaPO}_{4}$ dibasic, $32.0 \mathrm{~g} \mathrm{NaCl}, 2.0 \mathrm{ml}$ Tween 20 , and $4.0 \mathrm{ml}$ tap water; $\mathrm{pH} 7.3$ ) three times for $3 \mathrm{~min}$ each. Two-hundred microliters of purified anti-WSMV IgG $(1 \mu \mathrm{g} / \mathrm{ml})$ in V/C buffer (20 g Sigma polyvinyl-pyrrolidone, $2 \mathrm{~g}$ ovalbumin, 1 liter ELISA wash) was added to each well and incubated at room temperature for $2 \mathrm{~h}$, and then washed as described above. The IgG was purified by mixing $6.5 \mathrm{ml}$ of phosphate-buffered saline (PBS) and $7.5 \mathrm{ml}$ of saturated ammonium sulfate to $1.0 \mathrm{ml}$ of WSMV antiserum and allowed to sit on ice for $1 \mathrm{~h}$. The mixture was centrifuged at $10,000 \mathrm{rpm}$ for $10 \mathrm{~min}$ and resuspended in $1.0 \mathrm{ml}$ of PBS. Goat antirabbit IgG-alkaline phosphatase conjugate (1:3,200 in V/C buffer; Sigma Chemical Co., St. Louis, MO) was then added to each well and incubated for another $2 \mathrm{~h}$, washed as above, and $p$-nitrophenyl phosphate (PNP) $(1 \mathrm{mg} / \mathrm{ml}$ in diethanolamine buffer, $\mathrm{pH}$ 9.8) was added. Plates were incubated in the light at room temperature for $30 \mathrm{~min}$ and then optical density at 405 $\mathrm{nm}$ was measured with a Molecular Devices E-max microplate reader (Molecular Devices, Menlo Park, CA). Triplet wells of each treatment, a carbonate buffer control, a mock-inoculated control (healthy Stephens), and an inoculated control (Stephens) were included on each plate. Peripheral wells of all plates remained empty.

ELISA readings were considered positive if absorbance readings were at least three times greater than the healthy control. Preliminary studies indicated that ELISA values were positive when one out of three or four plants per pot were symptomatic. Statistical analyses were not conducted due to the qualitative nature of the assay. A line was considered susceptible if a positive reading was expressed in one or more replicates or resistant if all readings were negative.

Cephalosporium stripe. Perennial wheat lines were screened for resistance to C. gramineum under controlled environment conditions. Madsen (PI 511673) and Stephens winter wheat cultivars (both susceptible), WA7437 (moderately resistant), and AT3425 (highly resistant) were included as controls. Seeds were imbibed in petri dishes on moist filter paper at $4^{\circ} \mathrm{C}$ for 4 days to synchronize germination, then sown into sand-filled galvanized steel flats and placed in a growth chamber at $15^{\circ} \mathrm{C}$ with $12 \mathrm{~h}$ of light. Plants were pulled from the sand when most of the seedlings were at the two-leaf-stage of growth and then transplanted four per pot, into $15.2-\mathrm{cm}$ diameter pots filled with Thatuna silt loam soil mix (described above). Prior to planting, each pot was weighed and filled with 1,315 g oven-dry equivalent of soil. Pots were drenched with water once a week to maintain gravimetric soil water content at $40 \%$ (approximately $-0.01 \mathrm{MPa}$ ) (1). Soil moisture was maintained with regular watering between drenches. Plants were fertilized every 2 weeks by adding $50 \mathrm{ml}$ of 300 $\mathrm{mg} /$ liter Nutriculture to each pot.

Inoculum preparation and inoculation. A wild-type isolate of $C$. gramineum (Cg84-30) originally isolated from Stephens winter wheat was used. Ten-mmdiameter plugs of corn meal agar colonized by Cg84-30 were removed from petri dishes with a sterile dissecting needle and added one or two at a time to $50 \mathrm{ml}$ of sterilized potato dextrose broth in 250-ml flasks. Liquid cultures were incubated at room temperature on a rotary shaker (70 to $90 \mathrm{rpm}$ ). After 5 to 8 days of growth the cultures were strained through a double layer of sterile cheesecloth to remove the mycelium from the suspension. The suspension was centrifuged for 15 to $20 \mathrm{~min}$ at $6,300 \mathrm{rpm}(\sim 5,468 \mathrm{~g})$ at room temperature. The supernatant was discarded and the pellet was resuspended in distilled 
water and centrifuged a second time. Spore concentration was calculated with the aid of a hemacytometer and adjusted to $1 \times 10^{6}$ spores per $\mathrm{g}$ of soil with tap water.

Immediately after transplanting, plants were inoculated by pouring $150 \mathrm{ml}$ of a conidial suspension on the soil surface of each pot (26). Plants were reinoculated with $50 \mathrm{ml}$ of conidia prepared in the same manner 1, 2, and 3 weeks after the initial inoculation, for a total of four inoculations over a 3-week-long prevernalization period. Fresh inoculum was prepared for each inoculation.

After the last inoculation, plants were vernalized at $4^{\circ} \mathrm{C}$ for 6 weeks with a 10 -h photoperiod. Plants were then moved to a greenhouse and allowed to grow until shortly after anthesis, about 6 to 8 weeks, when disease was evaluated.

Disease evaluation. Plants were rated visually for disease expression during the early stages of kernel development. Individual stems in each pot were rated on a 0 to 5 scale where $5=$ a dead stem (white head); 4 = chlorotic stripes and or necrotic vascular bundles on the flag leaf; $3=$ chlorotic stripes and or necrotic vascular bundles on the leaf below the flag leaf; $2=$ chlorotic stripes and or necrotic vascular bundles on the second leaf below the flag leaf; $1=$ chlorotic stripes and or necrotic vascular bundles on the third leaf below the flag leaf; and $0=$ no symptoms in the uppermost four leaves (27). Disease incidence was expressed as the percentage of symptomatic stems per pot and disease severity was calculated as the mean rating of symptomatic stems. Disease index was calculated by multiplying disease incidence by disease severity and dividing by five to obtain a value ranging from 0 to 100 (27).

Experimental design and data analysis. Pots were arranged in a randomized complete block design with five replicates per line. The experiment was repeated. Data were analyzed with analysis of variance (ANOVA) using SAS statistical analysis software (SAS Institute, Cary, NC). Means were separated using Fisher's protected LSD $(P=0.05)$. A line was considered susceptible if its mean disease index was significantly greater or resistant if it was not significantly greater than the resistant controls (AT3425 and WA7437).

Eyespot. Perennial lines were screened for resistance to eyespot under controlled environment conditions using a modified method of de la Peña and Murray (5). Madsen and VPM-1 were included as resistant controls and Eltan as a susceptible control.

Seeds were imbibed on moist filter paper in petri dishes at $4^{\circ} \mathrm{C}$ for 4 days to synchronize germination. Two seeds of each genotype were sown in 5-cmdiameter pots in a Thatuna silt loam and covered with approximately $2 \mathrm{~cm}$ of $2: 1$ vermiculite/TSL. Plants were grown in a growth chamber at $15^{\circ} \mathrm{C}$ with $12 \mathrm{~h}$ of light and 98 to $100 \%$ relative humidity. Pots were arranged in flats (up to 50 pots per flat) and approximately 2 to 3 liter of water was added to each flat once a week. Plants were fertilized every 2 weeks by adding a solution of $300 \mathrm{mg} / \mathrm{liter}$ Nutriculture to the flats after seedling emergence.

Inoculum preparation and inoculation. A $\beta$-D-glucuronidase (GUS)-transformed strain of $T$. yallundae (tPhmon8) was used as inoculum (5). Cultures on potato dextrose agar were cut into small pieces, macerated in sterile water, spread on water agar plates, and incubated under continuous UV light at $16^{\circ} \mathrm{C}$ for 2 to 3 weeks to induce sporulation. Plates were periodically agitated to maintain moisture across the agar surface, and sterile water was added as necessary to avoid drying. Conidia were harvested by scraping the agar plates with a bent glass rod and counted with a hemacytometer. They were then added to a water agar slurry to give a final concentration of $1 \times 10^{5}$ conidia per $\mathrm{ml}(5)$.

A drinking straw approximately $3.2 \mathrm{~cm}$ long $\times 6.0 \mathrm{~mm}$ wide and split along its length was placed around the coleoptile of each plant near the soil line. When plants reached the 1.5- to 2-leaf-stage of growth, $250 \mu \mathrm{l}$ of the inoculum slurry was placed in the straw collar of each plant (5). Plants were reinoculated the next day using the same volume and slurry.

Table 1. Reaction to Wheat streak mosaic virus (WSMV) of perennial wheat lines in three experiments under controlled environment conditions

\begin{tabular}{|c|c|c|c|c|}
\hline \multirow[b]{2}{*}{ Line } & \multicolumn{3}{|c|}{ Number of positive plants per total ${ }^{a}$} & \multirow[b]{2}{*}{ Phenotype $^{d}$} \\
\hline & Experiment $1^{\text {b }}$ & Experiment $2^{b}$ & Experiment $3^{c}$ & \\
\hline Noninoculated control & $0 / 5$ & $0 / 5$ & $0 / 5$ & \\
\hline MT-2 & $0 / 5$ & $0 / 5$ & $0 / 5$ & $\mathrm{R}$ \\
\hline PI 206624 & $0 / 5$ & $0 / 5$ & $0 / 5$ & $\mathrm{R}$ \\
\hline PI 264770 & $0 / 5$ & $0 / 5$ & $0 / 5$ & $\mathrm{R}$ \\
\hline PI 550713 & $0 / 5$ & $0 / 5$ & $0 / 5$ & $\mathrm{R}$ \\
\hline PI 550715 & $0 / 5$ & $0 / 5$ & $0 / 5$ & $\mathrm{R}$ \\
\hline SS103 & $0 / 5$ & $0 / 5$ & $0 / 5$ & $\mathrm{R}$ \\
\hline SS237 & $0 / 5$ & $0 / 5$ & $0 / 5$ & $\mathrm{R}$ \\
\hline SS452 & $0 / 5$ & $0 / 5$ & $0 / 5$ & $\mathrm{R}$ \\
\hline AT3425 & $0 / 5$ & $0 / 5$ & $5 / 5$ & $\mathrm{~S}$ \\
\hline SS191 & $0 / 5$ & $1 / 5$ & $4 / 5$ & $\mathrm{~S}$ \\
\hline SS679 & $0 / 5$ & $5 / 5$ & $\ldots$ & $\mathrm{S}$ \\
\hline SS49 & $5 / 5$ & $5 / 5$ & $\ldots$ & $\mathrm{S}$ \\
\hline SS56 & $5 / 5$ & $5 / 5$ & $\ldots$ & $\mathrm{S}$ \\
\hline SS60 & $5 / 5$ & $5 / 5$ & $\ldots$ & $\mathrm{S}$ \\
\hline SS241 & $3 / 5$ & $5 / 5$ & $\ldots$ & $\mathrm{S}$ \\
\hline SS259 & $2 / 5$ & $3 / 5$ & $\ldots$ & $\mathrm{S}$ \\
\hline SS364 & $3 / 5$ & $4 / 5$ & $\ldots$ & $\mathrm{S}$ \\
\hline SS365 & $2 / 5$ & $5 / 5$ & $\ldots$ & $\mathrm{S}$ \\
\hline SS485 & $5 / 5$ & $5 / 5$ & $\ldots$ & $\mathrm{S}$ \\
\hline SS498 & $5 / 5$ & $5 / 5$ & $\ldots$ & $\mathrm{S}$ \\
\hline SS524 & $5 / 5$ & $5 / 5$ & $\ldots$ & $\mathrm{S}$ \\
\hline SS744 & $5 / 5$ & $5 / 5$ & $\ldots$ & $\mathrm{S}$ \\
\hline SS767 & $3 / 5$ & $4 / 5$ & $\ldots$ & $\mathrm{S}$ \\
\hline SS791 & $3 / 5$ & $5 / 5$ & $\ldots$ & $\mathrm{S}$ \\
\hline Inoculated control & $5 / 5$ & $5 / 5$ & $5 / 5$ & $\mathrm{~S}$ \\
\hline
\end{tabular}

${ }^{a}$ Enzyme-linked immunosorbent assay (ELISA) absorbance readings were considered positive (susceptible) if values were threefold greater than those of the healthy check.

${ }^{\mathrm{b}}$ Plants were tested for WSMV by ELISA 18 days after the second inoculation.

${ }^{c}$ Only plants resistant in experiments 1 and 2 were evaluated. The temperature was raised to $25^{\circ} \mathrm{C} 18$ days after the second inoculation and plants were tested using ELISA 2 weeks later.

d A line was considered susceptible ( $\mathrm{S}$ ) if a positive reading was expressed in one or more replicates, or resistant $(\mathrm{R})$ if all readings were negative.
Disease evaluation. Plants were evalu-
ated for disease severity 6 weeks after inoculation. The shoots of each plant were clipped approximately $1.5 \mathrm{~cm}$ above the removed from the pots, the roots discarded, and the lowermost $4 \mathrm{~cm}$ of each plant was with tap water to remove ally for disease severity using a 1 to 4 scale modified from de la Peña and Murray (5) lesions) on the first or second sheath (hypersensitive reaction); $3=$ a well-defined $=$ lesion(s) girdling or covering over twothirds of the area of the first and second further analyses.

Colonization was further quantified by plant. GUS activity was determined by the conversion of 4-methylumbelliferyl $\beta$-Dferone (MU) by GUS (5). GUS activity was expressed as nm of MU produced per ground in $2.5 \mathrm{ml}$ of extras $\mathrm{mM}$ NaHPO4, pH 7.0, $5 \mathrm{mM}$ dithiothreitol, $10 \mathrm{mM} \mathrm{Na}_{2}$ EDTA, $0.1 \%$ sodium lauryl where: $1=$ no disease; $2=$ a lesion on the measuring GUS produced by the trans-

growth chamber at $15^{\circ} \mathrm{C}$ with 12 h of light 
sarcosine, $0.1 \%$ Triton $\mathrm{X}-100$ ) and the extract was poured into $1.2 \mathrm{ml}$ microfuge tubes and frozen at $-20^{\circ} \mathrm{C}$ until analyses.

GUS determinations were conducted by adding $40 \mu \mathrm{l}$ of MUG substrate to $50 \mu \mathrm{l}$ of sample in 1.2-ml plastic tubes and then incubating them at $37^{\circ} \mathrm{C}$ for $60 \mathrm{~min}$. Adding $1.0 \mathrm{ml}$ of $0.2 \mathrm{M}$ sodium carbonate to each tube stopped the reaction. Two hundred microliters of each sample was then transferred into individual wells of black microtiter plates, and fluorescence determined immediately with a fluorimeter (Dynatech Laboratories, Inc., Chantilly, VA). Each plate included two MUG, extraction buffer and stop buffer checks, and four MU standards of different concentration.

Experimental design and data analyses. Pots were arranged in a randomized complete block design with six replicates. The experiment was repeated. The second experiment differed from the first in that disease evaluation and GUS activity were determined only from the main stem rather than all stems on a plant. Both visual and GUS data were analyzed by ANOVA using SAS statistical analysis software. GUS scores were transformed logarithmically due to the nonnormal distribution of the rated using Fisher's protected LSD $(P=$ $0.05)$. Individual lines were considered means and variances. Means were sepa-

susceptible if the GUS score was significantly greater or resistant if the GUS score was not significantly different from the resistant control (Madsen).

\section{RESULTS}

Wheat streak mosaic. All samples with visible symptoms of WSM reacted positively for the presence of WSMV in the ELISA assay. Individual lines varied in their reaction to WSMV in repeated experiments (Table 1), but all inoculated controls reacted positively and all mockinoculated healthy controls reacted negatively for the presence of WSMV as determined by ELISA.

Eleven of the 24 perennial lines were resistant in the first experiment (Table 1) and nine of those 11 lines were resistant in the second experiment. AT3425 was resistant in the first two experiments, but tested positive in the third experiment after the temperature was raised to $25^{\circ} \mathrm{C}$ and was considered susceptible.

Cephalosporium stripe. There were significant $(P<0.05)$ differences among perennial lines for disease incidence and severity in both experiments and, therefore, disease index was used to compare lines (Table 2). Homogeneity of variance did not differ significantly between experiments, and thus, the data were combined for analysis. Disease did not develop on PI

Table 2. Cephalosporium stripe disease index for perennial wheat lines determined in two controlled environment experiments

\begin{tabular}{|c|c|c|c|c|}
\hline Line & Experiment $1^{a}$ & Experiment 2 & Mean & Phenotype $^{b}$ \\
\hline PI 264770 & 0 & 0 & 0 & $\mathrm{R}$ \\
\hline PI 206624 & 0 & 0 & 0 & $\mathrm{R}$ \\
\hline SS452 & 0 & 0 & 0 & $\mathrm{R}$ \\
\hline MT-2 & 0 & 1.7 & 0.9 & $\mathrm{R}$ \\
\hline PI 550713 & 0.5 & 2.0 & 1.3 & $\mathrm{R}$ \\
\hline SS191 & 0.9 & 2.9 & 1.9 & $\mathrm{R}$ \\
\hline SS103 & 2.4 & 2.3 & 2.4 & $\mathrm{R}$ \\
\hline SS679 & 0 & 4.7 & 2.4 & $\mathrm{R}$ \\
\hline SS364 & 3.7 & 2.5 & 3.1 & $\mathrm{R}$ \\
\hline AT3425 (control) & 0.2 & 7.3 & 3.8 & $\mathrm{R}$ \\
\hline SS237 & 8.0 & 2.7 & 5.4 & $\mathrm{R}$ \\
\hline SS365 & 4.5 & 12.8 & 8.7 & $\mathrm{R}$ \\
\hline SS259 & 0.6 & 21.5 & 11.1 & $\mathrm{R}$ \\
\hline WA7437 (control) & 7.1 & 16.9 & 12.0 & $\mathrm{R}$ \\
\hline PI 550715 & 9.1 & 20.6 & 14.9 & $\mathrm{R}$ \\
\hline Madsen (control) & 26.0 & 36.9 & 31.5 & $\mathrm{~S}$ \\
\hline SS791 & 22.9 & 41.4 & 32.2 & $\mathrm{~S}$ \\
\hline SS524 & 30.3 & 36.3 & 33.3 & $\mathrm{~S}$ \\
\hline SS241 & 29.2 & 41.0 & 35.1 & $\mathrm{~S}$ \\
\hline Stephens (control) & 37.9 & 32.6 & 35.3 & $\mathrm{~S}$ \\
\hline SS744 & 27.5 & 43.4 & 35.5 & $\mathrm{~S}$ \\
\hline SS485 & 34.6 & 50.9 & 42.8 & $\mathrm{~S}$ \\
\hline SS60 & 50.6 & 35.2 & 42.9 & $\mathrm{~S}$ \\
\hline SS498 & 47.6 & 49.0 & 48.3 & $\mathrm{~S}$ \\
\hline SS56 & 39.6 & 62.1 & 50.9 & $\mathrm{~S}$ \\
\hline SS49 & 63.8 & 38.7 & 51.3 & $\mathrm{~S}$ \\
\hline SS767 & 48.2 & 57.6 & 52.9 & $\mathrm{~S}$ \\
\hline $\operatorname{LSD}^{\mathrm{c}}(P=0.05)$ & 13.7 & 15.1 & 10.8 & \\
\hline
\end{tabular}

${ }^{a}$ Disease index is determined by multiplying the percent infected stems by the average disease severity (rated on a 0 to 5 scale where $0=$ no symptoms in the uppermost four leaves and $5=$ a dead stem), and dividing by 5 to obtain a value ranging from 0 to 100 .

${ }^{\mathrm{b}} \mathrm{A}$ line was considered susceptible (S) if its mean disease index was significantly greater or resistant (R) if it was not significantly different than the resistant controls (AT3425 and WA7437).

${ }^{c}$ LSD $=$ Fisher's least significant difference. Values within columns represent the mean of five replicates with four plants per replicate.
206624, PI 264770, or SS452 in either experiment; disease indices for eight other perennial lines were less than 6.0 when averaged across experiments, and all were considered resistant. By comparison, average disease indices for Madsen and Stephens, the susceptible controls, were 31.5 and 35.3 , respectively. The average disease indices of 10 perennial lines were the same or significantly greater than Madsen and Stephens and were considered susceptible.

Eyespot. Homogeneity of variance differed significantly for disease index but not for GUS score between experiments and thus, they were analyzed separately. GUS scores differed significantly among perennial lines in the first experiment $(P=$ 0.0001) (Table 3). GUS scores for MT-2 and PI 206624 were significantly $(P \leq$ $0.05)$ less than Madsen, and 11 other perennial lines had GUS scores that were not statistically different from Madsen; all were considered resistant. All other perennial lines had GUS scores that were significantly greater than Madsen and were considered susceptible. Disease indices ranged from 1.0 to 3.5 and, with the exception of SS744, was consistent with GUS scores in assigning phenotype (Table 3 ).

GUS scores likewise differed significantly among lines in the second experiment $(P<0.05)$ (Table 3$)$. Fourteen perennial lines had GUS scores that were not statistically different from Madsen and were considered resistant. Disease indices ranged from 1.3 to 3.2 and with the exception of SS237 and SS452 was consistent with GUS score in assigning phenotype.

Four perennial lines differed in their reaction between experiments. Lines SS679 and SS744 were resistant in the first experiment and susceptible in the second. In contrast, lines SS241 and SS56 were susceptible in the first experiment but resistant in the second.

\section{DISCUSSION}

Lines MT-2, PI 550713, PI 550715, SS103, SS237, and SS452 were resistant to Cephalosporium stripe, wheat streak mosaic, and eyespot based on our tests. The wheatgrasses Thinopyrum intermedium (PI 264770) and Thinopyrum ponticum (PI 206624) were likewise resistant to these three diseases. Genes from the wheatgrasses confer perennial habit and are also the probable source of resistance to these diseases. Lines SS49, SS56, SS60, SS485, SS498, SS524, and SS791 were susceptible to all three pathogens and although the objective of this work was to identify potential sources of resistance for development of perennial wheat cultivars, these susceptible lines may be useful as controls in future studies and as parental lines in genetic studies.

Lines SS452, SS679, MT-2, PI 206624, and PI 264770 did not develop symptoms of Cephalosporium stripe in the first 
greenhouse experiment and had low or no disease in the second experiment (Table 2). Although Cephalosporium stripe developed to some extent on SS237, SS259, and SS365, these lines were considered resistant since the mean disease index for each was statistically equal to AT3425, the resistant control. Similar results were obtained from a field plot near Ritzville, WA that was naturally infested with $C$. gramineum (unpublished data). Previous work also demonstrated effective resistance to Cephalosporium stripe in A. elongatum and A. intermedium (20). Mathre and Johnston (19) showed that movement of $C$. gramineum was slower through roots and especially in crown tissues of $A$. elongatum and $A$. intermedium than in wheat lines. Resistance to $C$. gramineum has been transferred from AT3425 to wheat and is being used for the development of winter wheat cultivars. Some of these lines have been grown in field plots for more than 5 years now and the resistance has remained effective (Jones and Murray, unpublished).

Eleven lines were resistant to WSMV in the first experiment, nine were resistant in the second experiment, and all but one of these nine was resistant at the higher temperature in the third experiment (Table 1). PI 206624 and PI 264770 were also resistant to WSMV, which agrees with previous work $(6,21)$. Mite resistance, another approach for limiting the spread of WSMV, was first identified by Andrews and Slykhuis (2) in hybrids derived from crosses of wheat x A. elongatum and A. intermedium. Resistance gene Wsml from A. intermedium confers resistance to WSMV and to wheat curl mite colonization (6).

It should be noted that some lines had a variable reaction to WSM in these experiments. Specifically, not all plants of lines SS191, 241, 259, 364, 365, 767, and 791 reacted positively in ELISA tests in one or more experiments. It is possible that these lines are heterogeneous for resistance to WSM or still segregating for resistance. Indeed, subsequent work with fluorescent in situ hybridization (FISH) has indicated that plants within some SS lines (e.g., 241) carry unequal numbers of telocentric chromosomes that may carry genes conferring WSM resistance ( $\mathrm{Li}$ and Murray, unpublished). For the sake of simplicity and because our goal was to identify potential parents for a breeding program, we elected to classify plants as susceptible or resistant.

Anecdotal observations (Murray and Jones, unpublished) indicated that AT3425 was susceptible to WSM under field conditions, but it did not develop symptoms and tested negative for presence of WSMV by ELISA in the first two experiments. The temperature was increased to $25^{\circ} \mathrm{C}$ after inoculation in the third experiment, and plants were allowed to grow 2 weeks longer than in the first two experiments. Three days after raising the temperature, chlorotic spots and streaks were visible on the young leaves of some plants of AT3425. Two weeks after the temperature was increased, mosaic was evident on all plants of AT3425 and ELISA readings were positive.

The absence of symptoms and positive ELISA reactions for AT3425 in the first two experiments may be the result of genetic instability (14) but is more likely due to a temperature sensitive resistance. Seifers et al. (25) showed that when certain $A$. intermedium-wheat translocation lines are inoculated 11 days following planting at $20^{\circ} \mathrm{C}$ under controlled conditions they are resistant to WSM, but not at $27^{\circ} \mathrm{C}$. These lines carried only the short arm of the $A$. intermedium chromosome 4Ai-2. Although WSM resistance in these lines was temperature sensitive, it appeared stable enough to protect against disease under field conditions. AT3425 is currently being used as a parent in the development of new adapted perennial lines, but the usefulness of resistance to WSM derived from it under field conditions needs further investigation in light of these data.

Based on GUS and visual data from the first experiment, PI 264770, PI 206624, and MT-2 are more resistant to T. yallundae than Madsen. Resistance to T. yallun- dae exists in other wild wheats (18), but has not been reported previously in the genus Thinopyrum. It would be worthwhile to characterize resistance in these species to further broaden the genetic base of resistance genes available to wheat breeding programs and to facilitate the incorporation of this resistance into perennial lines.

Eyespot resistance in this study was determined using an isolate of $T$. yallundae (formerly W pathotype). However, recent data indicates that T. acuformis (formerly $\mathrm{R}$ pathotype) has become more prevalent in the Pacific Northwest during the last 10 years (Douhan and Murray, unpublished). Resistance to T. acuformis has not been evaluated fully in wheat and its relatives, and recent evidence suggests that different genes may condition resistance to this species (35). Further work is needed to characterize resistance to $T$. acuformis given its increased prevalence and to ensure eyespot resistance in perennial wheat is effective against both pathogen species.

Of the perennial amphiploids that were resistant to all three diseases in this study, MT-2 has been used as a parent in perennial wheat and forage grass breeding programs elsewhere, although sterility is high and progeny lines are unable to sustain

Table 3. Eyespot disease severity and $\beta$-D-glucuronidase (GUS) scores for perennial wheat lines determined in two experiments.

\begin{tabular}{|c|c|c|c|c|c|c|}
\hline \multirow[b]{2}{*}{ Line } & \multicolumn{3}{|c|}{ Experiment 1} & \multicolumn{3}{|c|}{ Experiment 2} \\
\hline & $\mathbf{D S}^{\mathbf{a}}$ & GUS score $^{b}$ & Phenotype $^{c}$ & DS & GUS score & Phenotype \\
\hline MT-2 & $1.0^{\mathrm{d}}$ & 0.56 & $\mathrm{R}$ & 1.5 & 0.68 & $\mathrm{R}$ \\
\hline PI 206624 & 1.1 & 0.68 & $\mathrm{R}$ & 1.3 & 0.85 & $\mathrm{R}$ \\
\hline PI 264770 & 1.1 & 0.72 & $\mathrm{R}$ & 1.5 & 0.97 & $\mathrm{R}$ \\
\hline VPM (control) & 1.4 & 0.82 & $\mathrm{R}$ & 1.5 & 1.04 & $\mathrm{R}$ \\
\hline PI 550715 & 1.3 & 0.84 & $\mathrm{R}$ & 1.5 & 0.74 & $\mathrm{R}$ \\
\hline PI 550713 & 1.7 & 0.91 & $\mathrm{R}$ & 1.8 & 0.98 & $\mathrm{R}$ \\
\hline AT3425 & 1.5 & 0.93 & $\mathrm{R}$ & 1.4 & 0.87 & $\mathrm{R}$ \\
\hline Madsen (control) & 1.7 & 1.00 & $\mathrm{R}$ & 1.5 & 1.00 & $\mathrm{R}$ \\
\hline SS 259 & 1.7 & 1.01 & $\mathrm{R}$ & 1.6 & 0.90 & $\mathrm{R}$ \\
\hline SS 679 & 1.6 & 1.03 & $\mathrm{R}$ & 2.4 & 1.40 & $\mathrm{~S}$ \\
\hline SS 237 & 2.2 & 1.08 & $\mathrm{R}$ & 2.1 & 1.25 & $\mathrm{R}$ \\
\hline SS 452 & 1.6 & 1.09 & $\mathrm{R}$ & 2.2 & 1.32 & $\mathrm{R}$ \\
\hline SS 103 & 2.2 & 1.23 & $\mathrm{R}$ & 1.5 & 1.14 & $\mathrm{R}$ \\
\hline SS 744 & 2.3 & 1.23 & $\mathrm{R}$ & 2.2 & 1.70 & $\mathrm{~S}$ \\
\hline SS 767 & 2.0 & 1.25 & $\mathrm{R}$ & 1.9 & 1.12 & $\mathrm{R}$ \\
\hline SS 191 & 2.3 & 1.30 & $\mathrm{~S}$ & 2.8 & 1.95 & $\mathrm{~S}$ \\
\hline SS 364 & 2.8 & 1.38 & $\mathrm{~S}$ & 2.27 & 1.36 & $\mathrm{~S}$ \\
\hline SS 241 & 2.3 & 1.44 & $\mathrm{~S}$ & 1.3 & 0.63 & $\mathrm{R}$ \\
\hline SS 498 & 2.3 & 1.45 & $\mathrm{~S}$ & 2.8 & 2.02 & $\mathrm{~S}$ \\
\hline SS 365 & 2.5 & 1.46 & $\mathrm{~S}$ & 1.8 & 1.36 & $\mathrm{~S}$ \\
\hline Eltan (control) & 2.6 & 1.55 & $\mathrm{~S}$ & 3.1 & 1.96 & $\mathrm{~S}$ \\
\hline SS 49 & 2.9 & 1.55 & $\mathrm{~S}$ & 2.9 & 1.94 & $\mathrm{~S}$ \\
\hline SS 485 & 2.9 & 1.60 & $\mathrm{~S}$ & 2.9 & 1.97 & $\mathrm{~S}$ \\
\hline SS 56 & 2.7 & 1.61 & $\mathrm{~S}$ & 2.0 & 1.07 & $\mathrm{R}$ \\
\hline SS 524 & 3.0 & 1.66 & $\mathrm{~S}$ & 3.2 & 2.16 & $\mathrm{~S}$ \\
\hline SS 791 & 3.0 & 1.70 & $\mathrm{~S}$ & 3.1 & 1.74 & $\mathrm{~S}$ \\
\hline SS 60 & 3.5 & 1.89 & $\mathrm{~S}$ & 2.5 & 1.40 & $\mathrm{~S}$ \\
\hline $\operatorname{LSD}^{\mathrm{e}}(P=0.05)$ & 0.6 & 0.29 & $\ldots$ & 0.4 & 0.35 & $\ldots$ \\
\hline
\end{tabular}

a DS = average disease severity of symptomatic stems on a 0 to 4 scale, where $1=$ healthy and $4=$ lesions covering over two-thirds of the stem base.

${ }^{\mathrm{b}} \beta$-D-glucuronidase (GUS) scores are expressed as the ratio of the accession to the resistant control (Madsen) plus one $\left[\log _{10}(\mathrm{X} /\right.$ Madsen $\left.\left.)+1\right)\right]$. Lines more resistant than the control have values less than one and lines more susceptible than the control have values greater than one.

${ }^{c}$ Individual lines were considered susceptible (S) if the GUS score was significantly greater or resistant (R) if the GUS score was not significantly different from the resistant control.

$\mathrm{d}$ Values within columns represent the mean of five replicates with two plants each.

e LSD $=$ Fisher's least significant difference. 
yield over time (14). Relative to wheat, most of the amphiploids are difficult to thresh, their spikelets are smaller, and the heads are less compact. For example, the average seed weight of MT-2 is almost three times greater than $A$. intermedium, but less than half that of a typical annual wheat cultivar (16). In related field studies, the amphiploids appeared vigorous in field plots located near Ritzville and Kahlotus, WA, once they were established. MT-2 emerged poorly, but was the most vigorous of all amphiploids tested once established (Murray and Jones, unpublished).

Resistance to eyespot, Cephalosporium stripe, and WSM was identified in several perennial wheat amphiploids using growth chamber tests in this study. Further work is needed to transfer resistance to these diseases into adapted perennial and annual wheat lines and test it under field conditions before it is known how useful they will be on a commercial scale.

\section{ACKNOWLEDGMENTS}

Plant Pathology New Series No. 0336, College of Agriculture and Home Economics Research Center, Project 0670, Washington State University, Pullman 99164-6240. Gratefully acknowledged is the financial support of the O. A. Vogel Wheat Research Fund and Fund for Rural America, Grant \#97-36200-5183.

\section{LITERATURE CITED}

1. Anderegg, J. C., and Murray, T. D. 1988. Influence of soil matric potential and soil $\mathrm{pH}$ on Cephalosporium stripe of winter wheat in the greenhouse. Plant Dis. 72:1011-1016.

2. Andrews, J. E., and Slykhuis, J. T. 1956. Reaction of winter wheat varieties and Triticum $\times$ Agropyron hybrids when inoculated with wheat streak mosaic virus by the mite vector Aceria tulipae Keifer. Plant. Dis. Rep. 40:513-516.

3. Clark, M. F., and Adams, A. N. 1977. Characteristics of the microplate method of enzymelinked immunosorbent assay for the detection of plant viruses. J. Gen. Virol. 34:475-483.

4. Cook, R. J., and Murray, T. D. 1987. Management of soilborne pathogens of wheat in soil conservation systems. Pages 314-323 in: STEEP - Conservation Concepts and accomplishments. L. F. Elliot, ed., Washington State Universtiy Publications, Pullman.

5. de la Peña, R. C., and Murray, T. D. 1994. Identifying wheat genotypes resistant to eyespot disease with $\beta$-glucuronidasetransformed strain of Pseudocercosporella herpotrichoides. Phytopathology 84:972-979.

6. Friebe, B., Gill, K. S., Tuleen, N. A., and Gill,
B. S. 1996. Transfer of wheat streak mosaic virus resistance from Agropyron intermedium into wheat. Crop Sci. 36:857-861.

7. Friebe, B., Jiang, J., Ruapp, W. J., McIntosh, R. A., and Gill, B. S. 1996. Characterization of wheat-alien translocations conferring resistance to diseases and pests: current status. Euphytica 91:59-87.

8. Fults, J. L. 1944. Some factors affecting the establishment of perennial grass for erosion control in eastern Colorado. J. Am. Soc. Agron. 36:615-625.

9. Gebhart, D. L., Johnson, H. B., Mayeux, H. S., and Polley, H. W. 1994. The CRP increases soil organic carbon. J. Soil Water Conserv. 49:488-492.

10. Herman, T., and Weise, M. V. 1985. Influence of cultural practices on incidence of foot rot in winter wheat. Plant Dis. 69:948-950.

11. Huggins, D. R., Allen, D. L., Gardner, J. C., Karlen, D. L., Bezdicek, D. F., Rosek, M. J., Alms, M. J., Flock, M., Miller, B. S., and Staben, M. L. 1997. Enhancing carbon sequestration in CRP-managed land. Pages 323-334 in: Management of Carbon Sequestration in Soil. R. Lal, J. M. Kimble, R. F. Follett, B. A. Stewart, eds. CRC Press, Boca Raton, FL.

12. Jones, S. S., and Murray, T. D. 1997. Development and feasibility of perennial wheat for highly erodible lands. USDA-Fund for Rural America, Grant \#97-36200-5183.

13. Jones, S. S., Murray, T. D., and Allan, R. E. 1995. Use of alien genes for the development of disease resistance in wheat. Annu. Rev. Phytopathol. 33:429-443.

14. Jones, T. A., Zhang, X. Y., and Wang, R. C. 1999. Genome characterization of MT-2 perennial and OK-906 annual wheat $\times$ intermediate wheatgrass hybrids. Crop Sci. 39:10411043.

15. Juahar, P. P., and Peterson, T. S. 1996. Thinopyron and Lophopyrum as sources of genes for wheat improvement. Cereal Res. Commun. 24:15-21.

16. Jurgen, S. S., and Haler, S. E. 1987. Registration of Montana-2 perennial $\times$ Agrotriticum intermediodurum Khizhnyak. Crop Sci. 27:822-823.

17. Lindstrom, M. J., Schumacher, T. E., and Blecha, M. L. 1994. Management considerations for returning CRP lands to crop production. J. Soil Water Conserv. 49:420-425.

18. Martin, T. J. 1978. Procedures for evaluating wheat streak mosaic virus resistance. Plant Dis. Rep. 62:1062-1066.

19. Mathre, D. E., and Johnston, R. H. 1990. A crown barrier related to Cephalosporium stripe resistance in wheat relatives. Can. J. Bot. 68:1511-1514.

20. Mathre, D. E., Johnston, R. H., and Martin, J. M. 1985. Sources of resistance to Cephalosporium gramineum in Triticum and Agropyron species. Euphytica 34:419-424.

21. McKinney, H. H., and Sando, W. J. 1951. Susceptibility and resistance to the wheat streak mosaic virus in the genera Triticum, Agropyron, Secale, and certain hybrids. Plant Dis. Rep. 35:476-478.

22. Murray, T. D. 1996. Resistance to benzimidazole fungicides in the cereal pathogen, Pseudocercosporella herpotrichoides, in the $\mathrm{Pa}-$ cific Northwest 1984-1990. Plant Dis. 80:1923.

23. Murray, T. D., Parry, D. W., and Cattlin, N. D. 1998. A Color Handbook of Diseases of Small Grain Cereal Crops. Iowa State University Press, Ames.

24. Ryan, M. R., Burger, L. W., and Kurzejeski, E. W. 1998. The impact of CRP on avian wildlife: a review. J. Prod. Agric. 11:61-66

25. Seifers, D. L., Martin, T. J., Harvey, T. L., and Gill, B. S. 1995. Temperature sensitivity and efficacy of wheat streak mosaic virus resistance derived from Agropyron intermedium. Plant Dis. 79:1104-1106.

26. Specht, L. P., and Murray, T. D. 1989. Sporulation and survival of conidia of Cephalosporium gramineum as influenced by soil $\mathrm{pH}$, soil matric potential, and soil fumigation. Phytopathology 79:787-793.

27. Specht, L. P., and Murray, T. D. 1990. Effects of root-wounding and inoculum density on Cephalosporium stripe in winter wheat. Phytopathology 80:1108-1114.

28. Suneson, C. A. 1959. Perennial wheat offered. Ann. Wheat Newsl. 6:34-35.

29. Suneson, C. A., and Pope, W. K. 1946. Progress with Triticum $\times$ Agropyron crosses in California. J. Am. Soc. Agron. 38:956-963.

30. Tzitzin, N. V. 1934. The Triticum $\times$ Agropyron hybrids. (Abstr.) Plant Breed. 5:24-25.

31. Tzitzin, N. V. 1940. Distant hybridizationthe chief method of breeding. Breed Seed Grow. 10:4-7.

32. USDA. 1978. Palouse Cooperative River Basin Study. US Government Printing Office, Washington, D.C

33. USDA-Economic Research Service. 1996. Agriculture and water quality. U.S. Dep. Agric. Washington, D.C.

34. USDA-Economic Research Service. 1996 Report to congress, 305B. U.S. Dep. Agric. Washington, D.C.

35. Uslu, E., Miller, T. E., Rezanoor, N. H., and Nicholson, P. 1998. Resistance of Dasypyrum villosum to the cereal eyespot pathogens, Tapesia yallundae and Tapesia acuformis. Euphytica 103:203-209.

36. Vinall, H. N., and Hein, M. A. 1937. Breeding miscellaneous grasses. Pages 1032-1102 in: Yearbook of Agriculture. USDA, U.S. Gov. Printing Office, Washington, D.C.

37. Wagoner, H. P. 1985. Brief summary of research: Development of perennial grain cropping systems at the Rodale Research Center (1982-1984). Rodale Research Center, Rodale Press, Emmaus, PA.

38. Wiese, M. V. 1987. Compendium of Wheat Diseases. American Phytopathological Society, St. Paul, MN. 